\title{
Pure white cell aplasia and health food products
}

\author{
PD Forsyth, JM Davies
}

\begin{abstract}
Summary
The safety of 'health' foods and complementary medicine products is increasingly questioned. We report a case of pure white cell aplasia developing in a patient who took a variety of such products leading to an excessive intake of zinc. Recovery was complete following the withdrawal of her 'medications'. The aetiology of the pure white cell asplasia is discussed with respect to the ingredients of the products ingested.
\end{abstract}

Keywords: pure white cell aplasia, dietary supplements, toxicity

The safety of 'health food/complementary medicine' products is increasingly being called into question. We report a novel adverse reaction to such products, namely, pure white cell aplasia.

\section{Case report}

A 62-year-old woman of Polish origin, who had no significant past medical history, presented to casualty with abdominal pain which was demonstrated to be due to constipation. On admission a full blood count revealed a total white cell count of $0.3 \times 10^{9} / 1$ with complete absence of granulocytes from the blood film. The haemoglobin and platelet count were nor$\mathrm{mal}$ at $12.8 \mathrm{~g} / \mathrm{dl}$ and $262 \times 10^{9} / 1$. Bone marrow examination showed a total lack of granulocytic precursors thus confirming a diagnosis of pure white cell aplasia.

On close questioning, the patient denied taking either prescription or over-the-counter medication. Her only 'medications' were products obtained from a Health Food shop. She had been consuming vitamin $\mathrm{E}$ for three years, garlic extract for two years, multivitamins and selenium/zinc for 12 months and a selection of oils for $\mathbf{8}$ months. The ingredients are listed in the table.

Investigation was undertaken to detect any possible underlying autoimmune process. An autoantibody screen (including antinuclear, antireticulin, antimitochondrial, antismooth muscle, antiparietal and antithyroid cytoplasm antibodies) was negative and bone marrow culture in the presence of the patients' serum (obtained 5-days postwithdrawal of admission 'medication') did not reveal any inhibitory factors. Computed tomography (CT) showed no evidence of a thymoma. Toxicological investigation showed a serum seleniun level of
$2.53 \mu \mathrm{mol} / 1$ (normal up to $1.75 \mu \mathrm{mol} / \mathrm{l}$ ) and was reported as being consistent with dietary supplementation. Serum zine was reported as being greater than $40 \mu \mathrm{mol} / 1$ (normal 11-24 $\mu \mathrm{mol} / 1)$. Serum copper was not measured.

Treatment was instituted with granulocytecolony stimulating factor (G-CSF). Antibiotic therapy (ceftazidime and gentamicin) required for a pyrexial episode (blood cultures negative) led to the development of an urticarial rash which resolved upon withdrawal of the ceftazidime. A normal neutrophil count was restored after seven days (at which point the G-CSF was stopped) and has remained normal for five months. Rechallenge with the admission medication has not been undertaken.

\section{Discussion}

Pure white cell aplasia is a rare (7.2 cases per million population), ${ }^{1}$ but serious disorder with an approximate $10-16 \%$ mortality, ${ }^{2,3}$ It most commonly occurs as a drug reaction. This may either be idiosyncratic or dose-dependent. Rarely, it may develop as an autoimmune phenomenon. ${ }^{4}$ It has not previously been reported in association with health food or complementary medicine products nor with any other constituent of a normal diet. The potential for each of the products to have been the cause for our patient's illness is discussed below.

The combination of the multivitamin preparation plus the combined selenium/zinc preparation led to the patient having a zinc intake of $35.9 \mathrm{mg} /$ day which exceeds the recommended daily allowance of $15 \mathrm{mg} /$ day. ${ }^{9}$ Zinc has been reported to induce neutropenia as part of a reversible sideroblastic anaemia via impairment of copper absorption. ${ }^{5,6}$ The other features of zinc toxicity are summarised in box 1. The zinc dosage in this case was considerably lower than that reported in association with sideroblastic anaemia $(100-300 \mathrm{mg} / \text { day })^{9}$ but impaired copper absorption has been documented with zinc doses only slightly above the recommended daily allowance., ${ }^{9,10}$ Although prolonged exposure to zinc may lead to hypocupraemia, this has not been reported in association with pure white cell aplasia.

Selenium toxicity is exceedingly rare in humans. It is seen most commonly in cattle where chronic exposure has induced anaemia. Pure white cell aplasia has never been reported as a consequence of selenium toxicity in man. An intake of greater than $1 \mathrm{mg} /$ day (National poisons unit communication) is thought to be 
Table Ingredients of health food products

\begin{tabular}{|c|c|c|c|}
\hline \multicolumn{4}{|l|}{ Forte-E-Vite Plus } \\
\hline Vitamin E & $200 \mathrm{IU}$ & & \\
\hline \multicolumn{4}{|l|}{ Bioselenium + Zinc } \\
\hline Selenium & $112 \mu \mathrm{g}$ & & \\
\hline Zinc & $26 \mathrm{mg}$ & & \\
\hline \multicolumn{4}{|c|}{$\begin{array}{l}\text { Quest super once-a-day timed release multiple vitamins and chelated } \\
\text { minerals }\end{array}$} \\
\hline Vitamins & & Minerals & \\
\hline A & $750 \mu \mathrm{g}$ & Calcium & $122 \mathrm{mg}$ \\
\hline D & $10 \mu \mathrm{g}$ & Phosphorus & $64 \mathrm{mg}$ \\
\hline C & $150 \mathrm{mg}$ & Iron & $15 \mathrm{mg}$ \\
\hline $\mathbf{E}$ & $34 \mathrm{mg}$ & Magnesium & $20 \mathrm{mg}$ \\
\hline B1 & $39 \mathrm{mg}$ & Zinc & $10 \mathrm{mg}$ \\
\hline B2 & $50 \mathrm{mg}$ & Iodine & $100 \mu \mathrm{g}$ \\
\hline B3 & $50 \mathrm{mg}$ & Potassium & $10 \mathrm{mg}$ \\
\hline B6 & $41 \mathrm{mg}$ & Manganese & $1 \mathbf{m g}$ \\
\hline Folate & $200 \mu \mathrm{g}$ & Copper & $1 \mathrm{mg}$ \\
\hline B12 & $50 \mu \mathrm{g}$ & Chromium & $25 \mu \mathrm{g}$ \\
\hline Biotin & $50 \mu \mathrm{g}$ & Selenium & $25 \mu g$ \\
\hline Pantothenic acid & $50 \mathrm{mg}$ & Vanadium & $25 \mu \mathrm{g}$ \\
\hline \multicolumn{4}{|l|}{ Additional factors } \\
\hline Choline & $50 \mathrm{mg}$ & Lecithin & $15 \mathrm{mg}$ \\
\hline Inositol & $50 \mathrm{mg}$ & Papain & $2 \mathrm{mg}$ \\
\hline Methionine & $50 \mathrm{mg}$ & Rutin & $2 \mathrm{mg}$ \\
\hline PABA & $50 \mathrm{mg}$ & Betaine $\mathrm{HCl}$ & $12 \mathrm{mg}$ \\
\hline Citrus bioflavonoids & $25 \mathrm{mg}$ & Hesperdin & $10 \mathrm{mg}$ \\
\hline Lysine & $22 \mathrm{mg}$ & Cysteine & $0.6 \mathrm{mg}$ \\
\hline \multicolumn{4}{|c|}{ Kyolic odourless garlic extract } \\
\hline Aged garlic & $100 \mathrm{mg}$ & & \\
\hline Lecithin & $65 \mathrm{mg}$ & & \\
\hline Oat bran & $60 \mathrm{mg}$ & & \\
\hline \multicolumn{4}{|c|}{ Gamma marine evening primrose, borage and fish oil } \\
\hline Linoleic acid & $280 \mathrm{mg}$ & & \\
\hline Linolenic acid & $80 \mathrm{mg}$ & & \\
\hline Eicosapentaenoic acid & $45 \mathrm{mg}$ & & \\
\hline Docosahexaenoic acid & $30 \mathrm{mg}$ & & \\
\hline
\end{tabular}

required before toxicity would be seen in humans. Our patient was only ingesting $112.8 \mu \mathrm{g} /$ day.

Pure white cell aplasia has not been associated with ingestion of linolenic or linoleic acids or fish oils. However, it has been hypothesised that alteration in arachadonic acid metabolism may be involved in the pathogenesis of agranulocytosis, aplastic anaemia, and leukaemia. This is based on the fact that prostaglandins modify the immune response, modify genetic damage by drugs and chemicals, modulate gene action and have feedback control on some haematopoietic regulatory factors (eg, G-CSF). ${ }^{7}$ As yet there is no definite evidence to support this theory.

Vitamin E therapy is thought to alter neutrophil function by impairing production of the superoxide radical within the neutrophil

1 Strom BL, Carson JL, Schinnar R, Snyder ES, Shaw M Descriptive epidemiology of agranulocytosis. Arch Intern Med 1992; 152: 1475-80.

2 Julia A, Olana M, Bueno $J$, et al. Drug-induced agranulocytosis: prognostic factors in a series of 168 episodes. Br $\mathcal{H}$ Haematol 1991; 79: 366-71.

3 Young NS, Agranulocytosis. $\mathcal{F} A M A$ 1994; 271 : 935-8.

4 Marinone G, Roncoli B, Marinone MG. Pure white cell aplasia. Semin Haematol 1991; 28: 298-302.

5 Broun ER, Greist A, Tricot G, Hoffiman R. Excessive zinc ingestion. A reversible cause of sideroblastic anaemia and bone marrow depression. $9 A M A$ 1990; 264: 1441-3.

6 Simon SR, Branda RF, Tindle BF, Burns SL. Copper deficiency and sideroblastic anaemia associated with zinc ingestion. Am f Haematol 1988; 28: 181-3.
Features of zinc toxicity

Acute toxicity

- nausea/vomiting, epigastric pain, diarrhoea

Chronic toxicity

- copper deficiency: reversible sideroblastic anaemia

- iron deficiency: iron deficiency anaemia

- altered lipid profile: elevated low density lipoprotein, reduced high density lipoprotein

- impaired immunity: depressed lymphocyte proliferative index, neutrophil chemotaxis and phagocytosis

Box 1

\begin{tabular}{|l|}
\hline Learning points \\
\hline pure white cell aplasia is almost always due to \\
a drug reaction \\
- always ask patients about 'self' medication \\
do not assume that vitamins, minerals and \\
herbal products are harmless
\end{tabular}

Box 2

vacuoles but, again, has not been reported in association with pure white cell aplasia. Although excess vitamin consumption can prove toxic, ${ }^{10}$ none of the other ingredients of our patient's 'medicines' have been associated with pure white cell aplasia.

It is impossible to conclude definitely which constituent, if any, of the above dietary supplements induced our patient's illness. However, bone marrow toxicity is the most likely cause. Toxicology studies would appear to implicate zinc as it was consumed in excess and has been associated with haematological abnormalities. However, if an idiosyncratic reaction was to blame then any of the above may be the culprit compound. We feel that the cause of this patient's pure white cell aplasia is most likely idiosyncratic; as it is with most drug-induced cases. It is thought that the 'drug' in question may be adsorbed to, or alter, the surface membrane of myeloid committed stem cells. This may lead either to immune destruction of such stem cells or to inhibition of their maturation. ${ }^{4}$

This case adds to the concern that the so-called 'health food/complementary medicines' market should be more closely regulated. It also serves as a reminder that 'self-remedies' should be specifically enquired about while taking a case history.

7 Das UN. Agranulocytosis, aplastic anaemia, and leukaemia: relevance to arachidonic acid metabolism. Prostaglandins Leukot Essent Fatty Acids 1990; 39: 217-20

8 Fosmire GJ. Zinc toxicity. Am f Clin Nutr 1990; 51: 225-7. 9 Festa MD, Anderson HL, Dowdy RP, Ellersieck MR. Effect of zinc intake on copper excretion and retention in men. $\mathrm{Am}$ f Clin Nutr 1985; 41: 285-92.

10 Walter P. Supraphysiological dosages of vitamins and their implications in man. Experimentia 1991; 47: 187-91. 